\title{
Palladium-catalysed [3 + 2] Cycloaddition of Trimethylenemethane (TMM) and Fullerene. Observation of the Room-temperature Fluorescence Spectrum of the TMM- $\mathrm{C}_{60}$ Adduct
}

\author{
Lung-Lin Shiu, Tsung-I Lin, Shie-Ming Peng, Guor-Rong Her, Dar Der Ju, Syh-Kun Lin, Jyun-Hwei Hwang, \\ Chung Yuan Mou and Tien-Yau Luh*
}

Department of Chemistry, National Taiwan University, Taipei, Taiwan 106, Republic of China

The first synthesis of the parent TMM- $\mathrm{C}_{60}$ adduct 1 was achieved by means of $\mathrm{Pd}^{\circ}$-mediated [3+2] cycloaddition and its structure was unambiguously proved by spectroscopic means ( ${ }^{1} \mathrm{H}$ and ${ }^{13} \mathrm{C}$ NMR and MS); a pentane solution of the adduct 1 exhibited a fluorescence emission spectrum with $\lambda_{\max } 704 \mathrm{~nm}$ and vibronic fine structure at ambient temperature.

Since the discovery of the multigram synthesis of $\mathrm{C}_{60},{ }^{1}$ a number of organic and organometallic derivatives have been prepared..$^{-4}$ Late transition metals such as nickel triad and iridium can readily form stable complexes with $\mathrm{C}_{60} .{ }^{2}$ Cycloaddition reactions so far may be one of the most successful tools to derivatize $\mathrm{C}_{60} \cdot{ }^{3} \mathrm{~A}$ recent report concerning the synthesis and biological activities of the derivatives of trimethylenemethane (TMM) adducts ${ }^{4}$ prompted us to report a convenient synthesis of the parent $\mathrm{TMM}-\mathrm{C}_{60}$ adduct 1 by means of the transition metal-mediated organic reaction of $\mathrm{C}_{60}$.

Palladium-catalysed $[3+2]$ cycloaddition of $\mathrm{CH}_{2}=\mathrm{C}$ $\left(\mathrm{CH}_{2} \mathrm{OAc}\right) \mathrm{CH}_{2} \mathrm{SiMe}_{3} 2$ via a TMM-palladium intermediate with alkenes having electron-withdrawing substituent has been proved to be particularly useful for the synthesis of methylenecyclopentanes. ${ }^{5} \mathrm{It}$ is well documented that $\mathrm{C}_{60}$ is an electron deficient species and the reduction potential (e.g. the second or third wave $)^{6}$ of $\mathrm{C}_{60}$ is compatible with that of an $\alpha, \beta$ unsaturated carbonyl compound. ${ }^{7}$ Accordingly, palladiumcatalysed cycloaddition or 2 with $\mathrm{C}_{60}$ would provide a useful entry to prepare the parent TMM- $\mathrm{C}_{60}$ adduct 1 . However, treatment of $\mathrm{C}_{60}$ with 2 in the presence of a catalytic amount of palladium catalysts under various conditions ${ }^{5}$ resulted in the recovery of $\mathrm{C}_{60}$. On the other hand, when $\mathrm{C}_{60}$ was first mixed with a stoichiometric amount of $\left[\mathrm{Pd}\left(\mathrm{PPh}_{3}\right)_{4}\right]$ and 1 equiv. of

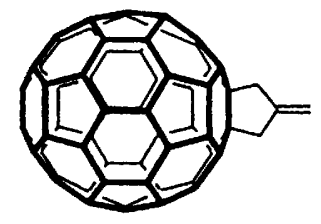

1

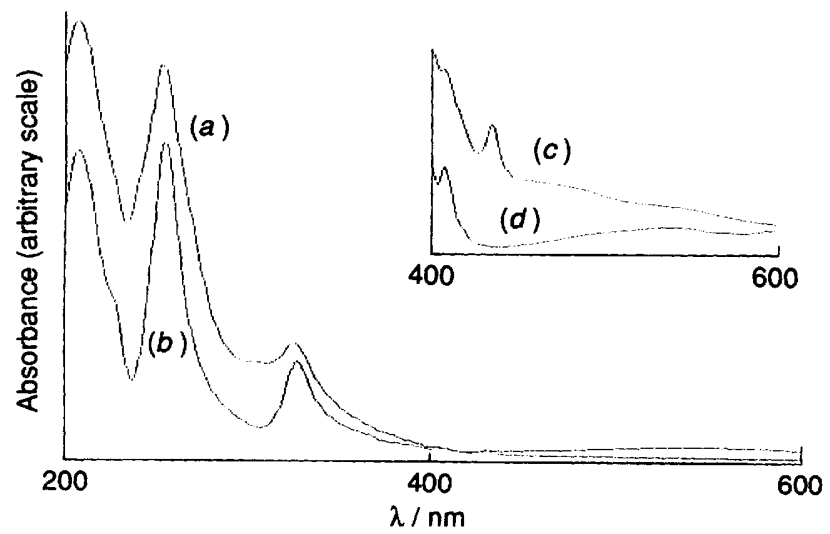

Fig. 1 The UV-VIS spectra of (a) $1.1 \times 10^{-5} \mathrm{~mol} \mathrm{dm}^{-3} 1$ in pentane (b) $5.2 \times 10^{-6} \mathrm{~mol} \mathrm{dm}^{-3} \mathrm{C}_{60}$ in pentane, (c) $1.0 \times 10^{-4} \mathrm{~mol} \mathrm{dm}^{-3} 1 \mathrm{in}$ benzene and $(d) 1.0 \times 10^{-4} \mathrm{~mol} \mathrm{dm}^{-3} \mathrm{C}_{60}$ in benzene. The molar absorptivities (in $10^{4} \mathrm{dm}^{3} \mathrm{~mol}^{-1} \mathrm{~cm}^{-1}$ ) are 7.6 at 207,6.9 at 254 and 2.1 at $326 \mathrm{~nm}$ in (a), and 5.3 at 406 and 3.7 at $433 \mathrm{~nm}$ in (c)
$\mathrm{Ph}_{2} \mathrm{PCH}_{2} \mathrm{CH}_{2} \mathrm{PPh}_{2}$ in benzene, a green solution was formed immediately, presumably, the corresponding palladium $-\mathrm{C}_{60}$ complex being formed. ${ }^{2 l}$ A benzene solution of 2 (3 equiv.) was then added slowly and the mixture was allowed to reflux under $\mathrm{N}_{2}$ for $72 \mathrm{~h}$. A reddish brown mixture was obtained. The solvent was removed and the residue was chromatographed on silica gel using hexane as the eluent; the TMM- $\mathrm{C}_{60}$ adduct 1 was obtained in $25 \%$ yield. The parent peak at $\mathrm{m} / \mathrm{z} 774$ for 1 was observed by desorption chemical ionization mass spectrometry in the negative ion mode and by the FAB method.

The ${ }^{1} \mathrm{H}$ NMR spectrum of 1 exhibited a two-proton

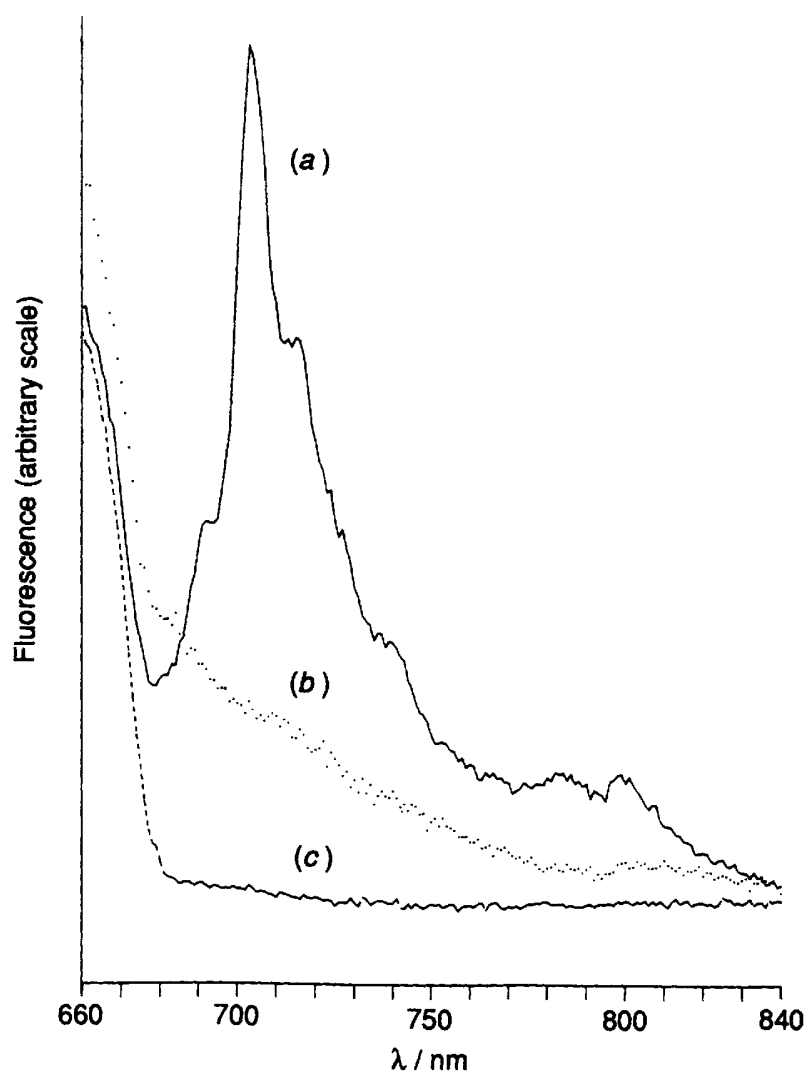

Fig. 2 Fluorescence emission spectra of $1(a)$ and $C_{60}(b)$ in pentane $\left(5.2 \mu \mathrm{mol} \mathrm{m^{-3 } )}\right.$ at $25^{\circ} \mathrm{C}$. Excitation wavelength $295 \mathrm{~nm}$ with band pass $16 \mathrm{~nm}$ and mission bandpass $2 \mathrm{~nm}$. Each curve was the average of five scans, $(c)$ shows the background of solvent pentane

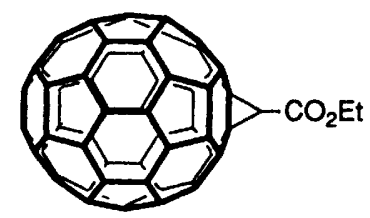

3 
multiplet centred at $\delta 5.63$ and a four-proton multiplet at $\delta 4.31$ due to the TMM moiety. The ${ }^{13} \mathrm{C}$ NMR spectrum was acquired at $75 \mathrm{MHz}$ in $\mathrm{CS}_{2}-\mathrm{CDCl}_{3}$ with $0.03 \mathrm{~mol} \mathrm{dm}^{-3}$ $\left[\mathrm{Cr}(\mathrm{acac})_{3}\right](\mathrm{acac}=$ acetylacetonate $)$ added as a relaxant. All twenty lines were observed. $\uparrow$ The fullerene region $(\delta 135-160)$ of the spectrum has three peaks corresponding to two carbon atoms and 13 corresponding to four carbon atoms in addition to the absorption attributed to the quaternary olefinic carbon of the substituent. The terminal olefinic carbon exhibited an absorption at $\delta 110.3$. The $\mathrm{sp}^{3}$ carbon of the fullerene skeleton appeared as a single peak at $\delta 69.0$ and the $\mathrm{CH}_{2}$ group at $\delta 48.4$. This result indicated that 1 has $C_{2 v}$ symmetry and the cycloaddition occurred at a two six-membered ring junction site.

The UV-VIS spectrum of 1 showed broad absorptions similar to those of many other $\mathrm{C}_{60}$ derivatives (Fig. 1). Intriguingly, the fluorescence emission spectrum of 1 (Fig. 2) appeared at $\lambda_{\max } 704 \mathrm{~nm}$ with vibronic fine structure $(694,704$, $714,725,739 \mathrm{~nm}$ ) which is quite similar to those observed for $\mathrm{C}_{60}$ in methylcyclohexane glass at $77 \mathrm{~K} .{ }^{9 d}$ The spectral characteristics obtained were independent of the excitation wavelength used (e.g. spectra obtained using excitation at 295 or $312 \mathrm{~nm}$ gave almost identical emission spectrum). This is the first fluorescence spectrum of a solution sample of a $C_{60}$ derivative measured at ambient temperature. $\$$ It is interesting that the methanofullerene $3^{8}$ also exhibited similar emission spectrum with $\lambda_{\max } 702 \mathrm{~nm}$.

Attempts to obtain a single crystal of 1 was only partially successful. The highly disordered tetragonal crystal with $a=$ $10.05, b=10.05$ and $c=30.32 \AA$ exhibited similar dimensions in the $a$ and $b$ axes as those in $\mathrm{C}_{60}{ }^{1}$

Support from the National Science Council of the Republic of China is gratefully acknowledged.

Received, 28th October 1993; Com. 3/06472G

\section{Footnotes}

† Spectroscopic data for 1. ${ }^{13} \mathrm{C}$ NMR $\delta 156.2,147.0,145.8,145.7$, 145.3, 145.2, 144.9, 144.8, 144.2, 142.7, 142.6, 142.2, 141.8, 141.6, 141.4, 139.7, 135.1, 110.3, 69.0, 48.4; IR v/cm-1 (KBr) 2913w, 2846w, $1667 \mathrm{w}, 1630 \mathrm{w}, 1507 \mathrm{w}, 1461 \mathrm{w}, 1424 \mathrm{w}, 1263 \mathrm{w}, 1181 \mathrm{br}, 895 \mathrm{w}, 865 \mathrm{w}$, $803 \mathrm{w}, 768 \mathrm{~s}, 707 \mathrm{~s}, 584 \mathrm{~s}, 574 \mathrm{vs}, 526 \mathrm{vs}$; UV-VIS ( $n$-hexane, nm) 207, 254, 326, 406, 433.

$\ddagger$ The fluorescence emission spectrum of $\mathrm{C}_{60}$ has been reported. ${ }^{9}$

\section{References}

1 W. Krätschmer, L. D. Lamb, K. Fostiropoulos and D. R. Huffman, Nature 1990, 347, 354.

2 (a) P. J. Fagan, J. C. Calabrese and B. Malone, Acc. Chem. Res., 1992, 25, 134; (b) J. M. Hawkins, Acc. Chem. Res., 1992, 25, 150; (c) A. L. Balch, J. W. Lee, B. C. Noll and M. M. Olmstead, J. Am. Chem. Soc., 1992, 114, 10984; (d) P. J. Fagan, J. C. Calabrese and
B. Malone, Science, 1991, 252, 1160; (e) J. M. Hawkins, A. Meyer, T. A. Lewis, S. Loren and F. J. Hollander, Science, 1991, 252, 312; (f) P. J. Fagan, J. C. Calabrese and B. Malone, J. Am. Chem. Soc., 1991, 113, 9408; (g) A. L. Balch, V. J. Catalano and J. W. Lee, Inorg. Chem., 1991, 30, 3980; (h) A. L. Balch, V. J. Catalano, J. W. Lee, M. M. Olmstead and S. R. Parkin, J. Am. Chem. Soc., 1991, 113, 8953; (i) A. L. Balch, V. J. Catalano, J. W. Lee and M. M. Olmstead, Angew. Chem., Int. Ed. Engl., 1992, 31, 1356; (j) R. S. Koefod, M. F. Hudgens and J. R. Shapley, J. Am. Chem. Soc., 1991, 113, 8957; (k) T. A. Pakkanen, M. Rasinkangas, T. T. Pakkanen, M. Ahlgren and J. Rouvinen, J. Am Chem. Soc., 1993, 115, 4901; (1) V. Bashilov, P. V. Petrovskii, V. I. Sokolov, S. V. Lindeman, I. A. Guzey and Y. T. Struchkov, Organometallics 1993, 12, 991.

3 F. Wudl, Acc. Chem. Res., 1992, 25, 157; M. Prato, Q. C. Li, F. Wudl and V. Lucchini, J. Am. Chem. Soc., 1993, 115, 1148; S. Shi, K. C. Khemani, Q. C. Li and F. Wudl, J. Am. Chem. Soc., 1992, 114, 10656; A. Vasella, P. Uhlmann, C. A. A. Waldraff, F. Diederich and C. Thilgen, Angew. Chem., Int. Ed. Engl., 1992, 31, 1388; T. Akasaka and W. Ando, J. Am. Chem. Soc., 1993, 115, 1605; Y. Elemes, S. K. Silverman, C. Sheu, M. Kao, C. S. Foote, M. M. Alvarez and R. L. Whetten, Angew. Chem., Int. Ed. Engl., 1992, 31, 351; K. M. Creegan, J. L. Robbins, W. K. Robbins, J. M. Millar, R. D. Sherwood, P. J. Tindall, D. M. Cox, A. B. Smith, III, J. P. McCauley, Jr., D. R. Jones and R. T. Gallagher, J. Am. Chem. Soc., 1992, 114, 1103; S. H. Hoke, II, J. Molstad, D. Dilettato, M. J. Jay, D. Carlson, B. Kahr and R. G. Cooks, J. Org. Chem., 1992, 57, 5069; P. Belik, A. Gugel, J. Spickermann and K. Mullen, Angew. Chem., Int. Ed. Engl., 1993, 32, 78; Y. Rubin, S. Khan, D. I. Freedberg and C. Yeretzian, J. Am. Chem. Soc., 1993, 115, 344; Y. Rubin, S. I. Khan, A. M. Oliver and M. N. PaddonRow, J. Am. Chem. Soc., 1993, 115, 4919; S. Yamago, H. Tokuyama, E. Nakamura, M. Prato and F. Wudl, J. Org. Chem. 1993, 58, 4796; M. Prato, V. Lucchini, M. Maggini, E. Stimpfl, G. Scorrano, M. Eiermann, T. Suzuki and F. Wudl, J. Am. Chem. Soc., $1993,115,8479$.

4 M. Prato, T. Suzuki, H. Foroudian, Q. Li, K. Khemani, F. Wudl, J. Leonetti, R. D. Little, T. White, B. Rickbon, S. Yamago and E. Nakamura, J. Am. Chem. Soc., 1993, 115, 1594; H. Tokuyama, S. Yamago, E. Nakamura, E. Shiraki and Y. Sugiura, J. Am. Chem. Soc., 1993, 115, 7918.

5 B. M. Trost and D. M. T. Chan, J. Am. Chem. Soc., 1983, 105, 2315; B. M. Trost and D. M. T. Chan, J. Am. Chem. Soc., 1983, $105,2326$.

6 Q. Xie, E. Perez-Cordero and L. Echegoyen, J. Am. Chem. Soc., 1992, 114, 3978; D. Dubois, K. M. Kadish, S. Flanagan, R. E. Haufler, L. P. F. Chibante and L. J. Wilson, J. Am. Chem. Soc., 1991, 113, 4364; D. Dubois, K. M. Kadish, S. Flanagan and L. J. Wilson, J. Am Chem. Soc., 1991, 113, 7773; Y. Ohsawa and T. Saji, J. Chem. Soc., Chem. Commun., 1992, 781.

7 M. M. Baizer, in Organic Electrochemistry, ed. M. M. Baizer, Marcel Dekker, New York, 1973, Chapter IX.

8 L. Isaacs, A. Wehrsig and F. Diederich, Helv. Chim. Acta, 1993, 76, 1231

9 (a) C. Reber, L. Yee, J. Mckiernan, J. I. Zink, R. S. Williams, W. M. Tong, D. A. A. Ohlberg, R. L. Whetten and F. Diederich, J. Phys. Chem., 1991, 95, 2127; (b) S. P. Libley, S. M. Argentine and A. H. Francis, Chem. Phys. Lett., 1992, 188, 187; (c) D. Kim and M. Lee, J. Am. Chem. Soc., 1992, 114, 4429; (d) Y. Wang, J. Phys. Chem., 1992, 96, 764; (e) Y.-P. Sun, P. Wang and N. B. Hamilton, J. Am Chem. Soc., 1993, 115, 6378; (f) J. Catalán and J. Elguero, J. Am. Chem. Soc., 1993, 115, 9249. 